\title{
Assessment by microflow fluorometry of the purity of interstitial cell suspensions from the rat testis
}

\author{
O. P. F. Clausen, K. Purvis and V. Hansson \\ Institute of Pathology, Rikshospitalet, Oslo, Norway
}

\begin{abstract}
Summary. The technique of microflow fluorometry (MFF) was used to identify the proportion of haploid cells (from the tubules) in interstitial cell suspensions. The MFF estimates of the degree of contamination by tubular elements correlated well with the numbers of cells with Leydig cell morphology and those staining positively for $3 \beta$ hydroxysteroid dehydrogenase.
\end{abstract}

\section{Introduction}

The availability of Leydig cell-enriched suspensions has contributed greatly to a better understanding of how various hormones are regulating androgen synthesis in the Leydig cells and the biochemical responses involved in these processes. However, such interstitial cell suspensions are always contaminated with tubular elements to various degrees, even when the same preparation procedure is used. There is a need for a technique which can provide a rapid and accurate assessment of the relative purity of these cell preparations.

The technique of microflow fluorometry (MFF) has been used in a variety of biological systems for the measurement of DNA distribution patterns of isolated and dispersed cells (Van Dilla, Trujillo, Mullaney \& Coulter, 1969; Göhde \& Dittrich, 1971). After suspension the cells are stained with a fluorochrome which binds quantitatively to the DNA. This fluorochrome emits pulses of fluorescent light in proportion to the DNA content of the cells when they are exposed to a beam of light in a pulse cytophotometer (flow cytofluorometer). Because the cells are excited one at a time in a fluid stream, the numbers of cells in each DNA class can be counted and a relative DNA distribution pattern can be produced for each cell suspension. Cells can be measured at a speed of $1000 \mathrm{cells} / \mathrm{sec}$ and DNA distributions can be obtained as histograms within 10-20 min (Crissman \& Tobey, 1974; Vindeløv, 1977). The method has been used to study cell ploidy in normal and malignant cell populations (Kraemer, Deaven, Crissman \& Van Dilla, 1972; Farsund, 1974; Laerum \& Mørk, 1975) and to perform detailed cell kinetic studies in vivo and in vitro (Tobey, 1972; Tobey \& Crissman, 1972; Rajewsky, Grüneisen \& Remmer, 1972; Schumann \& Göhde, 1974; Clausen \& Lindmo, 1976; Clausen, Gautvik \& Lindmo, 1977). The main advantage of the method is that many cells can be measured within a short time, resulting in a high degree of statistical precision.

Testicular cell suspensions from mature rats exhibited three distinct and normally distributed peaks of fluorescence when subjected to MFF measurements of nuclear DNA (unpublished results). The peaks represented haploid, diploid and tetraploid cells, and the haploid pulses were about $75 \%$ of the total number of pulses. In the testis, haploid cells are confined to the tubules and may therefore be used as markers for monitoring the degree of admixture of cells from the tubular compartment into suspensions of isolated interstitial cells. We therefore explored the application of MFF to DNA measurements of Leydig cell-enriched cell suspensions for assessment of the degree of contamination with tubular cells as a practical and time-saving method for control checks of interstitial cell suspensions.

\section{Materials and Methods}

Mature male rats were used in all experiments and isolated interstitial cells were prepared by the method of Moyle \& Ramachandran (1973) with little modification. Testes were decapsulated and the 
minced tissue was treated with collagenase. The cells were processed for MFF as described by Göhde \& Dittrich (1971) and were incubated in $0.5 \%$ pepsin before being stained with ethidium bromide (Berkhan, 1972). The DNA distributions were measured by an ICP 11 pulse cytophotometer (Phywe AG, Göttingen, W. Germany).

\section{Results and Discussion}

The histograms of the DNA Oistribution are shown in Text-fig. 1. The percentages of cells with haploid (1C), diploid (2C) and tetraploid (4C) DNA content were calculated by estimating the areas under the corresponding parts of the histograms. By using the number of haploid cells in the suspensions of

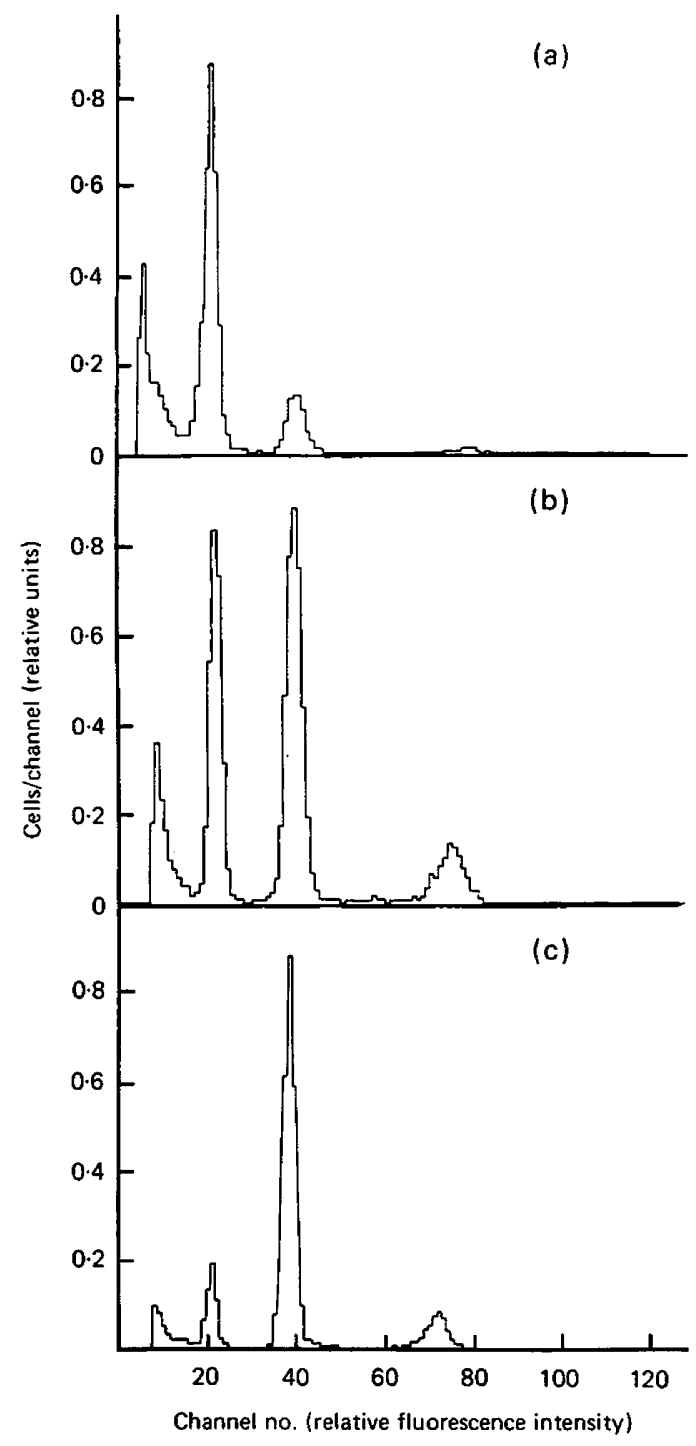

Text-fig. 1. Examples of DNA distribution patterns from (a) dispersed cells from the whole testis of a mature rat, and from (b, c) isolated interstitial cells with an admixture of $34.2 \%$ (b) and $14 \cdot 4 \%$ (c) haploid cells, reflecting a purity (see text) of 55.5 and $81.3 \%$ respectively. The normally distributed peaks located at about Channel 20 represent haploid cells, the peaks at Channel 40, diploid cells, and the third peak, tetraploid cells. Note the high haploid peak in suspensions from mature testes and the small peak in relatively pure interstitial cell suspensions. 
Table 1. Characteristics of various interstitial cell suspensions from rat testes

\begin{tabular}{|c|c|c|}
\hline $\begin{array}{c}\% \text { Purity by } \\
\text { MFF }\end{array}$ & $\begin{array}{l}\% \text { Morphological } \\
\text { Leydig cells }\end{array}$ & $\begin{array}{l}\% \text { Cells positive } \\
\text { for } 3 \beta-H S D\end{array}$ \\
\hline $18 \cdot 3$ & $11 \cdot 2$ & 10.0 \\
\hline $31 \cdot 6$ & $21 \cdot 4$ & $21 \cdot 6$ \\
\hline $38 \cdot 3$ & $19 \cdot 3$ & $23 \cdot 2$ \\
\hline $66 \cdot 9$ & 28.9 & $29 \cdot 9$ \\
\hline
\end{tabular}

interstitial cells as a measure of admixture of tubular cells, the purity of the interstitial cell suspensions was determined. The relative number of haploid cells in the interstitial cell population $(a)$ was calculated as a percentage of the relative number of haploid cells in a corresponding population of cells from a whole testis $(b)$, i.e. purity $=100(1-a / b)$. Because more than $75 \%$ of the cells in suspensions from mature testes are haploid, no great error is introduced even if haploid cells from the tubules are present in the preparations. This would tend to underestimate the purity of the cell suspensions. The proportion of Leydig cells in smears from isolated interstitial cells and from suspended cells from whole testes was estimated by counting cells with a morphology characteristic of that of Leydig cells and by scoring $3 \beta$-hydroxysteroid dehydrogenase ( $3 \alpha$-HSD)-positive cells in smears of unfixed cells (Levy, Deane \& Rubin, 1959).

Estimations of the proportion of Leydig cells in whole testicular suspensions did not exceed $3 \%$ whether identified by morphology or by the $3 \beta-$ HSD reaction, indicating that these suspensions can be considered as representative of a whole testis population. A typical DNA distribution pattern of testicular cells from a mature rat is shown in Text-fig. 1(a). DNA distribution from interstitial cell suspensions with 34.2 and $14.4 \%$ haploid cells (and therefore estimated purities of 55.5 and $81.3 \%$, respectively) are shown in Text-figs 1(b) and 1(c). The pulses to the left of the haploid peak at Channel 20 represent fluorescence from cell debris, non-specific fluorescence and fluorescence from spermatozoa, because pulses from suspensions of spermatozoa were mainly located to the left of the $1 \mathrm{C}$ peak. This finding is in agreement with the observation that spermatozoa need additional enzyme treatment (papain, pepsin) before they exhibit the same degree of fluorescence as spermatids (Zante, Schumann, Göhde \& Hacker, 1977). Table 1 shows that with increasing purities of interstitial cells, as estimated from MFF, there is a parallel increase in the proportion of morphological Leydig cells and 3 $\beta$-HSDpositive cells. The relative number of interstitial cells as calculated by MFF is almost twice the number of morphological Leydig cells or 3 $\beta$-HSD-positive cells which can be scored in the same suspension by cytological examination. The proportion of neutrophilic granulocytes, a measure of admixture of diploid cells from blood, was so low that blood cells could not account for the remaining interstitial cells. We therefore assume that this discrepancy is mainly due to connective tissue cells (fibrocytes, macrophages) and cells in early and morphologically uncharacteristic stages of the cycle of Leydig cell development within the interstitial cell compartment.

It is concluded than the present technique does constitute a method of estimating the proportion of interstitial cells in Leydig cell-enriched cell suspensions. Moreover, the proportional relationship between the relative number of interstitial cells and the relative number of Leydig cells indicates that DNA measurements provided by MFF can be used to supply an assessment of the proportion of Leydig cells in such suspensions.

\section{References}

BERKHAN, E. (1972) DNS-Messung von Zellen aus Vaginal-abstrichen Arztl. Lab. 18, 77-79.

Clausen, O.P.F. \& Lindmo, T. (1976) Regenerative proliferation of mouse epidermal cells following adhesive tape stripping. Cell Tissue Kinet. 9, 573-587.
Clausen, O.P.F., Gautvik, K.M. \& Lindmo, T. (1977) Cell cycle distributions, growth characteristics and variation in prolactin and growth hormone production in cultured rat pituitary cells. Virchows Arch. Abt. B: Cell. Path. 23, 195-207. 
Crissman, H.A. \& TOBey, R.A. (1974) Cell cycle analysis in 20 minutes. Science, N.Y. 184, 1297-1298.

FARSUND, T. (1974) Preparation of bladder mucosa cells for micro-flow fluorometry. Virchows Arch. Abt. B: Cell. Path. 16, 35-42.

Göhde, W. \& DitTrich, W. (1971) Impulsfluorometrie, ein neuartiges Durchflussverfahren zur ultraschnellen Mengenbestimmung von Zellinhaltstoffen. Acta histochem., Suppl. 10, 429-437.

Kraemer, P.M., Deaven, L.L., Crissman, H.A. \& Van Dilla, M.A. (1972) DNA constancy despite variability in chromosome number. Adv. cell. molec. Biol. 2, 47-103.

LAERUM, O.D. \& MøRK, S.J. (1975) DNA distribution in aneuploid tumour cell lines under different culture and transplantation conditions. In Proc. 2nd Int. Symp. Pulse-Cytophotometry, Münster, pp. 250-260. Eds J. Schumann, W. Göhde \& Th. Büchner. European Press, Ghent.

Levy, H., DeAne, H.W. \& Rubin, B.L. (1959) Visualization of steroid-3 $\beta$-ol-dehydrogenase activity in tissues of intact and hypophysectomized rats. Endocrinology 65, 932-943.

Moyle, W.R. \& Ramachandran, J. (1973) Effect of LH on steroidogenesis and cyclic AMP accumulation in rat Leydig cell preparations and mouse tumor cells. Endocrinology 93, 127-134.

Rajewsky, M.F., Grüneisen, A. \& Remmer, I. (1972) Modification of proliferative parameters by temporary inhibition of DNA synthesis. Studia biophys. 31/32, 367-374.

Schumann, J. \& Göhde, W. (1974) Die Zellkinetische Wirkung von Bleomycin auf das Ehrlich-Karzinom der Maus in vivo. Strahlentherapie 147, 298-307.

ToBey, R.A. (1972) Arrest of chinese hamster cells in $G_{2}$ following treatment with the antitumor drug Bleomycin. J. cell. Physiol. 79, 259-266.

Tobey, R.A. \& Crissmann, H.A. (1972) Use of flow microfluorometry in detailed analysis of effects of chemical agents on cell cycle progression. Cancer Res. 32, 2726-2732.

Van Dilla, M.A., Trujillo, T.T., Mullaney, P.F. \& COULTER, J.R. (1969) Cell microfluorometry: a method for rapid fluorescence measurement. Science, N.Y. 163, 1213-1214.

VINDELøv, L.L. (1977) Flow microfluorometric analysis of nuclear DNA in cells from solid tumours and cell suspensions. Virchows Arch. Abt. B: Cell. Path. 23, 227-242.

Zante, J., SchumanN, J., Göhde, W. \& Hacker, U. (1977) DNA fluorometry of mammalia sperm. Histochemistry 54, 1-7.

Received 26 September 1977 